\title{
EFFECT OF EJACULATION FREQUENCY AND BREED ON SEMEN CHARACTERISTICS AND SPERM OUTPUT OF RABBITS*
}

\author{
R. P. AMANN \\ Dairy Breeding Research Center, Department of Dairy Science, \\ The Pennsylvania State University, University Park, Pennsylvania, U.S.A.
}

(Received 19th October 1965)

\begin{abstract}
Summary. Six Dutch-type and nine New Zealand White rabbits were each ejaculated at frequencies of $1 \times 12 \mathrm{hr}, 1 \times 24 \mathrm{hr}$ and $2 \times 48 \mathrm{hr}$. Ejaculate volume and sperm concentration were lower $(P<0.01)$ at $1 \times 12 \mathrm{hr}$ than at either of the other two frequencies. Daily sperm output did not differ significantly among the three frequencies. Dutch-type rabbits had a significantly lower daily sperm output than New Zealand Whites.
\end{abstract}

Gregoire, Bratton \& Foote (1958) found that increasing the ejaculation frequency of rabbits from once weekly to once daily resulted in decreases of $50 \%$ in sperm concentration and $40 \%$ in ejaculate volume. Weekly sperm output, however, was almost $400 \%$ greater at the higher frequency. Desjardins, Kirton \& Hafs (1965) compared the sperm output of twelve rabbits each collected at four frequencies. Weekly sperm output $\left(\times 10^{-6}\right)$ averaged 273 with one ejaculate weekly, 519 with one ejaculate collected daily except Sundays and 619 when two successive ejaculates were collected each Monday, Wednesday and Friday.

The present study was designed to determine an ejaculation frequency which would maximize sperm output and to study breed differences in semen characteristics. Three groups, each consisting of two Dutch-type and three New Zealand White rabbits over 1 year old, were used in a change-over design. Body weight averaged $2.40 \mathrm{~kg}$ for Dutch-type and $3.88 \mathrm{~kg}$ for New Zealand White rabbits. Ejaculation frequencies tested with each rabbit were: one ejaculate each $12 \mathrm{hr}(1 \times 12 \mathrm{hr})$, one ejaculate each $24 \mathrm{hr}(1 \times 24 \mathrm{hr})$ and two ejaculates about $15 \mathrm{~min}$ apart each $48 \mathrm{hr}(2 \times 48 \mathrm{hr})$. Each ejaculation was preceded by one false mount. The male was allowed to mount the teaser doe, make a series of pelvic thrusts and then allowed or forced to dismount. Collection of the ejaculate by artificial vagina normally followed during the next mount. Each ejaculation frequency was imposed for 36 days; the 6-day adjustment period was followed by a 30-day experimental period.

* Authorized for publication on 6th October 1965 as paper No. 3070 in the journal series of the Pennsylvania Agricultural Experiment Station. 
After ejaculation, the collection tube was separated from the artificial vagina and the gel plug was removed if present. Ejaculate volume was read directly from the calibrated collection tube. Paired ejaculates for rabbits collected $1 \times 12 \mathrm{hr}$ or $2 \times 48 \mathrm{hr}$ were pooled before determination of sperm concentration by haemocytometer counts. Since some semen remains in the artificial vagina, residual spermatozoa were flushed with about $15 \mathrm{ml}$ distilled water from the latex liner into a small flask immediately after collection. Artificial vagina flushings were pooled for each rabbit on a 48-hr basis.

There were no statistically significant differences between the characteristics of ejaculates collected at $1 \times 24 \mathrm{hr}$ and $2 \times 48 \mathrm{hr}$ except for the percentage of ejaculates containing gel (Table 1). At $2 \times 48 \mathrm{hr}, 70 \%$ of the first ejaculates

TABLE 1

EFFECT OF EJAGULATION FREQUENCY

AND BREED ON CHARACTERISTICS OF RABBIT SEMEN

\begin{tabular}{|c|c|c|c|c|c|c|}
\hline Characteristic & $1 \times 12 h r$ & $1 \times 24 h r$ & $2 \times 48 h r$ & $\begin{array}{l}\text { Dutch- } \\
\text { type }\end{array}$ & $\begin{array}{c}\text { New Zealand } \\
\text { White }\end{array}$ & $\begin{array}{c}\text { Mean, } \\
\text { weighted } \\
\text { by rabbits }\end{array}$ \\
\hline $\begin{array}{l}\text { Volume/ejaculate }(\mathrm{ml}) \\
\text { Total volume } / 48 \mathrm{hr}(\mathrm{ml}) \\
\text { Sperm concentration } \\
\left(10^{6} / \mathrm{ml}\right) \\
\text { Daily sperm output (Dso) } \\
\left(10^{6}\right) \text { ) } \\
\text { Dso in flushings }(\%) \\
\text { Ejaculates containing gel } \\
(\%)\end{array}$ & $\begin{array}{c}0 \cdot 31^{* *} \\
1 \cdot 24^{* *} \\
152^{* *} \\
103 \\
12 \\
65\end{array}$ & $\begin{array}{r}0 \cdot 41 \\
0 \cdot 83 \\
\\
243 \\
\\
110 \\
10 \\
62\end{array}$ & $\begin{array}{c}0 \cdot 42 \\
0 \cdot 84 \\
260 \\
114 \\
10 \\
35^{* *}\end{array}$ & $\begin{array}{r}0.34 \\
0 \cdot 83 \\
\\
198 \\
\\
88 \\
12 \\
54\end{array}$ & $\begin{array}{c}0.41 \\
1 \cdot 06 \\
232 \\
123^{*} \\
10 \\
54\end{array}$ & $\begin{array}{r}0.38 \\
0 \cdot 97 \\
219 \\
109 \\
11 \\
54\end{array}$ \\
\hline
\end{tabular}

* Mean is significantly $(P<0.05)$ different from that for the other breed.

** Mean differs $(P<0 \cdot 01)$ from the means for the other two ejaculation frequencies.

contained a gel plug, but only $5 \%$ of the second ejaculates contained gel. In six of 225 pairs of ejaculates both the first and second ejaculates contained gel. First ejaculates $(0.45 \mathrm{ml})$ were larger $(P<0.01)$ than second ejaculates $(0.38 \mathrm{ml})$ during $2 \times 48 \mathrm{hr}$. Collection at $1 \times 12 \mathrm{hr}$ reduced $(P<0 \cdot 01)$ ejaculate volume and sperm concentration as compared to either $1 \times 24 \mathrm{hr}$ or $2 \times 48 \mathrm{hr}$. Morning and evening ejaculates during $1 \times 12 \mathrm{hr}$ averaged 0.31 and $0.31 \mathrm{ml}$ and $69 \%$ and $63 \%$ of these ejaculates contained gel.

Daily sperm output (Dso) was not significantly affected by ejaculation frequency. Including spermatozoa flushed from the artificial vagina, Dso averaged $109 \times 10^{6}$ cells and values for individual rabbits ranged from 48 to $174 \times 10^{6}$ cells. About $11 \%$ of the Dso was recovered in artificial vagina flushings which agrees with the value reported by Bredderman, Foote \& Yassen (1964) for a Waltonstyle artificial vagina. Excluding spermatozoa recovered in the flushings, the fifteen rabbits ejaculated an average of $679 \times 10^{6}$ spermatozoa/week. This value is about $10 \%$ greater than the weekly sperm output of $619 \times 10^{6}$ cells (without flushings) reported by Desjardins et al. (1965) for rabbits collected twice successively each Monday, Wednesday and Friday. However, these workers did not use false mounting for sexual preparation and found that second ejaculates 
contained more spermatozoa than first ejaculates. Possibly for these reasons, they obtained fewer spermatozoa $\left(519 \times 10^{6} /\right.$ week $)$ with collections daily except Sunday. In the present study, sperm counts were not made on individual successive ejaculates, but the volume of first ejaculates exceeded that of second ejaculates.

Dutch-type rabbits tended to have smaller and less concentrated ejaculates than New Zealand Whites, but the differences did not approach statistical significance. However, Dso for the Dutch-type rabbits was significantly lower $(P<0 \cdot 05)$. Mean Dso for the six Dutch-type rabbits of $88 \times 10^{6}$ cells was probably lowered about $8 \%$ by the value of $48 \times 10^{6}$ cells for one rabbit subsequently found to have only one active testis. If the value for this rabbit is doubled, the Dutch-type rabbits would have averaged $96 \times 10^{6}$ spermatozoa/day. This value agrees with that of about $101 \times 10^{6}$ spermatozoa/day for four Dutch-type rabbits collected once daily (Gregoire et al., 1958).

The number of spermatozoa recovered in the flushings was correlated with Dso $(r=0.47)$. The percentage of the Dso recovered in the flushings was correlated with ejaculate volume in the collection tube $(r=-0.44)$ but not with sperm concentration $(r=0 \cdot 11)$.

This study demonstrates that for most experiments where it is desirable to maximize Dso an ejaculation frequency of $2 \times 48 \mathrm{hr}$ can be used. This ejaculation frequency should be practical for most rabbits and, except for very critical in-vivo kinetic studies, should reveal the most information with the least amount of work.

This investigation was supported by U.S. Public Health Service Research Grant HD 01356-01 from the National Institute of Ghild Health and Human Development. The technical assistance of W. Lott is gratefully acknowledged.

\section{REFERENCES}

Bredderman, P. J., Foote, R. H. \& Yassen, A. M. (1964) An improved artificial vagina for collecting rabbit semen. 7. Reprod. Fert. 7, 401.

Desjardins, C., Kirton, K. T. \& Hafs, H. D. (1965) Rabbit sperm output after varying ejaculation frequencies. (Abstract). F. Anim. Sci. 24, 916.

Gregoire, A. T., Bratton, R. W. \& Foote, R. H. (1958) Sperm output and fertility of rabbits ejaculated either once a week or once a day for forty-three weeks. F. Anim. Sci. 17, 243. 